"Statuens eum in sede prodecessoris sui, et dans ei baculum pastoralem in manu sinistra, dicit," \&c.

This is of itself conclusive; but, in the next place, it is easy to adduce examples of abbots represented with the crosier in the left hand. I have before me a figure of Adam, abbot of St. Denis, in 1121, carrying his crosier in his left hand, and holding a book in his right. On the seal of Wilton, St. Giles, abbot, is represented with the crosier in his left; as he is in an old picture in my possession. So is St. Leonard, on the seal of his hospital in Leicester; and so is St. Columba, on an old monastic seal in my collection. Then on the monumental brass of the Abbot Esteney, at Westminster, the abbot is figured with the crosier in his left hand; and on the magnificent brass of the Abbot de la Mere, in St. Alban's, the crosier is laid on the abbot's left side. Dr. Rock, in his Church of our Futhers (vol. ii. p. 208), mentions an ancient figure of an abbot in Peterborough Cathedral, with the crosier in the same position; and he adds, that "the same may be observed in many of our abbatial seals, such as that for Crowland; for Pollesworth nunnery, and for Thorney." Though the present inquiry refers to abbots only, I may mention that St. Mildreda, abbess, on the seal of Tenterden, and St. Eanswede, abbess, on that of Folkestone, hold their crosier in their left hands. St. Gertrude, of Nivelles, has the crosier also in her left hand, in the plates of her in the Nouvelles Fleurs des Saintes, and in De Levens der Heylige van Nederlant, by Van Loo. I do not deny that abbots are often seen figured with the crosier in the right; but instances of its being held in the left are too common for any rule or distinctive mark to be grounded upon the former mode of representation.

F. C. $\mathrm{H}$.

ElrLy Extros in the Eninburah RBgister of Testaments. - The Register of Testaments of the Commissary Court of Edinburgh commences abruptly. The earlier volumes have not been preserved :-

"Sir William Fleminge Wiccar (?) $\mathrm{P}$ - of Kilbryd. $8 \mathrm{Maii}, 1564$.

David Guthrie, Pryor of the Abbey of St. Androis, A.D. 1564. Jane.

Sir Henry Sfow, Prebendar of Saint Geilleg Kirk, 3rd

John Betoun of Balfoure, 7 th June.

George Claphan (Clephan) of Carslogie, 10th June.

Katherine Auchmoutie; relict of umquhile Thomas Weymes of Louthank (?) 14 June.

Elizabeth Quhytlaw, spouse to William Newton of that Ilk, 15 June.

Johne Roberton of Ernok, 21 June.

James Hoppringill of Quhytbank, 22 June.

James Hoppringill of Bulholme, 3d July.

Mairteine Nicolsoune, Commone Crick in Edinburgh, 3 July.

Patrict Scot of Monzies, 8 July.

Thomas Grahame of Boquhoppill, $10 \mathrm{July.}$
Andw. Frazer of Stainwood, 12 July.

Gilbert Johnst on of Coreherd, $20 \mathrm{July}$.

Sir John Harstie, Wicar of Dalkeithe, 20 July.

Marion A vel Lady Balmain, $28 \mathrm{July}$.

Robert Bishope of Orknay, 4 Aug.

David Robson of Billie, 7 Aug.

IVilliam Ker, burges of Fdinburgh, 12 A ug.

James Bassinden, burges of Edinburgh, 15 Aug.

Thomas Tod Swordslipper, burges of Edinburgh, 9 October.

Katherine Brown, relict of umquhile W. James Foulis, of Collingtoun, 10 Oct.

Mr Edward Bruce, of Eister Kennet, 12 October.

Sir Williame Hoppringill, Prebendar of Borthloch, 18 Oct."

\section{J. MI.}

Coriosity at Berkelex Castie. - The following cutting from the Gloucester Mercury newspaper of Sept. 14, 1865, may be worthy a corner in "N.\& Q." :

"A curiosity las lately been added to Berkeley Castle -a monster Chinese bell. It has been raised ipon au ornamental iron frame in the outer court. Upon a small brass tablet is the following inscription:- "This bell was presented by Captain Roderick Dew, C.B., H.M.S. Endeavour, to his kind friend and patron, Admiral the Right Hon. Lord Fitzhardinge, G.C.B., under whose auspices he entered the navy, and served under his command in H.M. ships Hercules and Thunderer. It was brought from the ruins of a Buddhist temple at Tsekee, in China, which had been burnt by the Taepings, December, 1864.' The bell bears this inscriptiou, which has been translated by Dr. Lockhart, medical missionary, from Pekin :- Date, 3rd year of the Emperor Kieng-lung (A.D. 1725). Put up in the autumn month on a lucky day. The following faithful officers, gentry, and believing literati subscribed for the casting of the bell.' The names are all given in the large lower compartments. Names of men, 250 ; of women, 80 in all. The latter are distinguished by a peculiar letter or character. 'The large upper compartments contain Buddhist hymns and prayers."

S. R. T. M.

Urcommon RHyyes.-The following far-fetched rhymea have been produced at rarious times. Their composition is owing, chiefly to the denial that such could be found, or rather inrented. The first was sent by a correspondent from Stratford, Essex, to the Wolcome Guest, for November 9, 1861:-

$$
\begin{aligned}
& \text { "Sir, I hope it's no crime } \\
& \text { To send you the rhyme, }
\end{aligned}
$$

Tho' you say there none is for chimney :

To prove it's not true,

As stated by you,

Know this, Sir, I've found it in Rhymncy."

This refers to some mines bearing the name. The next is from The Athencum, and is a double example:-
"From the Indus to the Blorenge Came the Rajah in a month,
Eating now and then an orange, Conning all the day his Grunth."

The Blorenge is explained as a hill near Abergarenny, and the Grunth the sacred book of the Sikhs. 